\title{
Performance Evaluation of a 4-Stack Solid Oxide Module in
}

\section{Electrolysis Mode}

J. Aicart ${ }^{*}$, a, Z. Wuillemin ${ }^{\mathrm{b}}$, B. Gervasoni ${ }^{\mathrm{a}}$, D. Reynaud ${ }^{\mathrm{a}}$, F. Waeber ${ }^{\mathrm{b}}$, C. Beetschen ${ }^{\mathrm{b}}$, Y. Antonetti ${ }^{\mathrm{b}}$, A. Nescib ${ }^{\mathrm{b}}$ J. Mougin ${ }^{\mathrm{a}}$

${ }^{\text {a }}$ Univ. Grenoble Alpes, CEA, Liten, DTCH, 38000 Grenoble, France.

${ }^{\mathrm{b}}$ SOLIDpower SA, 26 av. des Sports, 1400 Yverdon-les-Bains, Switzerland

[*]Corresponding author: jerome.aicart@cea.fr 


\begin{abstract}
To support the current trend of testing bigger reversible Solid Oxide Cell (rSOC) modules, CEA has built the $120 \mathrm{~kW}$ DC Multistack platform. It was used to test SOLIDpower recently developed-Large Stack Module (LSM) in electrolysis mode.

Results show high thermal performance of the LSM, with homogeneous temperature distribution and losses in the kilowatt range above $700^{\circ} \mathrm{C}$. A performance map was recorded between 712 and $744^{\circ} \mathrm{C}$ over $22.4-$ to- $29.6 \mathrm{~kg} \mathrm{~h}^{-1}$ steam flowrates using a fast control strategy to avoid endothermic operation. A peak power of $74 \mathrm{~kW}$ DC was converted into more than $50 \mathrm{~kg} \mathrm{day}^{-1}$ of $\mathrm{H}_{2}\left(35.5 \mathrm{kWh}_{\mathrm{DC}} \mathrm{kgH}_{2}{ }^{-1}\right)$. In addition, fuel utilization of more than $90 \%$ and steam conversion above $80 \%$ were demonstrated at the module level. In the end, the modular design of the LSM seems well suited for system scale up, paving the way for mutualization of auxiliaries and CAPEX reduction.
\end{abstract}

\title{
Highlights
}

- CEA has built the Multistack platform to test rSOC modules of up to $120 \mathrm{~kW}$ DC

- SOLIDpower has developed the Large Stack Module integrating four G8X stack towers

- A peak power of $74 \mathrm{~kW}_{\mathrm{DC}}$ was converted into more than $50 \mathrm{~kg} \mathrm{day}^{-1}$ of $\mathrm{H}_{2}$

- Excellent thermal performances were recorded with losses in the $\mathrm{kW}$ range above $700^{\circ} \mathrm{C}$

\section{Keywords}

Electrochemistry, Fuel cells, Power Modulation, Reversible Solid Oxide Cell System (rSOC), Solid Oxide Electrolysis Cell (SOEC), Solid Oxide Fuel Cell (SOFC), Stack, Module, System. 


\section{Introduction}

Due to their intermittence and typical time shift between production and consumption peaks, renewable energy sources often require a form of storage to maximize the usable electrical output. This situation favors both $\mathrm{H}_{2}$ as an energy vector and electrochemical production systems based on high temperature Solid Oxide Cells (SOC). Indeed, the gaseous nature of $\mathrm{H}_{2}$ enables its massive storage and transportation with relative ease, consequently lifting time and distance limitations that often exist between renewable electricity generation and usage. In addition, High Temperature Electrolysis (HTE) has the potential to produce $\mathrm{H}_{2}$ at a much lower electrical cost than lower temperature technologies [1].

In this context, there has been a recent interest boost for $\mathrm{H}_{2}$ as an energy vector, particularly in Europe, both technological with numerous FCH-JU projects (70 projects funded by Horizon 2020), as well as political [2]-[4]. Both France and Germany, for example, have announced massive funding to ultimately develop a green hydrogen industry. The end-goal of many of the current efforts remains to successfully commission multi-MW clean $\mathrm{H}_{2}$-producing plants and address several major markets [5] such as mobility [6], heavy industries fueled by natural gas [7], or agriculture with ammonia production [8], [9].

While the current technological interest in Solid Oxide Electrolysis Cell (SOEC) technology is undeniable, building a $\mathrm{H}_{2}$-based industry and significantly decreasing the current fossil fuel consumption requires scaling up the size of HTE systems while achieving long term operation. A modular approach to system development is generally adopted. In this view, Sunfire GmbH is leading the effort in terms of installed power [10]. After successfully commissioning a $80 \mathrm{~kW}_{\text {DC }}$ system with 50\% LHV efficiency in the frame of GrInHy E.U. project [11] in 2019, Sunfire is currently testing their $720 \mathrm{~kW}$ AC GrInHy2.0 system producing $200 \mathrm{Nm}^{3} \mathrm{H}_{2} \mathrm{~h}^{-1}$ [12], [13]. The rapid power increase of their systems was made possible through the development of the HyLink module, with the Generation-1 incorporating 36 stacks [13]. Further scale-up is 
already on-going in the frame of the MultiPLHY E.U. project (Grant agreement ID: 875123), with a targeted HTE power of 2.5 MW.

The SOEC technology is also inherently reversible, and studies have been carried out at different scales, from half cells or single cells [14]-[17] to stacks [17], [18] to systems [19]. Aicart et al. [20] reported transitions of 10 minutes or less at the stack level between three different power levels and operating modes (SOEC, SOFC- $\left.\mathrm{H}_{2}, \mathrm{SOFC}-\mathrm{CH}_{4}\right)$. These results were integrated in a natural-gas compatible hybrid storage solution that combined a cathodesupported stack, an after-burner for co-generation, as well as a dual stage $\mathrm{H}_{2}$ compression system for $\mathrm{H}_{2}$ storage up to 185 bars [21]. The hybrid solution was further investigated, highlighting a promising sustainability and techno-economic potential [22]. Recently, Saarinen et al. [23] designed and manufactured a two-stack two-module system that was subsequently operated for more than $5000 \mathrm{~h}$. An AC-to- $\mathrm{H}_{2}$ efficiency of $81 \%$ (HHV, assuming free steam) was recorded, and the data acquired from extensive instrumentation provided insights on future system scale-up [23]. Finally, Ro. Peters et. al. [24] reported an impressive $9000 \mathrm{~h}$ of system operation on their $5 / 15 \mathrm{~kW}$ DC reversible SOE system. They recorded fast transitions between a wide range of sustainable operating conditions, a low degradation rate of $0.6 \% \mathrm{kh}^{-1}$ at $0.5 \mathrm{~A} \mathrm{~cm}^{-2}$, and announced a further scale-up of their system [24].

In the past years, SOLIDpower has become one of the major SOFC actors in Europe, focusing mainly on the development and commercialization of the Bluegen BG-15 micro-CHP unit [25], [26], while continuing the development of the technology for other markets and applications. With the opening of a new stack production plant in Italy in 2021 and the scale-up of its Bluegen assembly line in Germany, SOLIDpower is expected to rapidly expand the Bluegen fleet, with already more than 2000 systems installed worldwide.

In parallel, an upscaled stack design was engineered and prototyped in the Swiss innovation center of SOLIDpower, specially designed for the co-developed Large Stack Module (LSM). 
The LSM, which includes four of the new-generation stacks, is dedicated to industrial applications and is designed for reversible fuel cell and electrolysis operation. It can be operated with a variety of fuels including reformate, syngas or hydrogen.

In the frame of the FCH-JU project SWITCH, the LSM is planned to be used as a $75 \mathrm{~kW}_{\mathrm{DC}}$ steam electrolyzer whenever renewable power is available. In the absence of renewable power, the system allows to operate as a natural gas fueled, $25 \mathrm{~kW}$ power generator able to co-generate up to $20 \mathrm{~kg}$ day $^{-1}$ of hydrogen from excess heat.

After a first round of design validation at DLR Stuttgart in fuel cell mode [27], SOLIDpower has appointed CEA-Liten to validate the LSM for electrolysis operation.

Over the past 15 years, CEA-Liten has dedicated a research program to high temperature electrolysis (HTE), with SOEC testing at various scale combined with multi-scale modeling [15], [28]-[30], stack design and assembly [31], and more recently, small scale rSOC system design, commissioning and operation [20], [32], [33]. To support the current trend of larger module development, CEA has constructed the "Multistack" testing platform which currently allows investigating rSOC modules up to $120 \mathrm{~kW}_{\mathrm{DC}}$ maximum power. The very first use of the platform was to test SOLIDpower's LSM in electrolysis mode.

The present paper aims at presenting the LSM, the testing platform, and the experimental results related to the first evaluation of SOLIDpower's module operated in HTE mode. 


\section{Experimental Section}

\subsection{The Large Stack Module (LSM)}

The LSM, showed in Figure 1, includes four G8X stack towers integrated in a high-temperature enclosure. The G8X stack is based on SOLIDpower's patented interconnect technology, upscaled to accommodate four anode-supported cells per layer. Apart from the interconnects and balance-of-stack components, the cells and other components are the same as the ones used in SOLIDpower's standard G8-80 stack. The cells consist of a Ni-YSZ anode support, a thin YSZ electrolyte, a GDC barrier layer and a LSCF-GDC cathode. The fuel manifolding is made through one inlet/outlet port per interconnect, while the air manifolding is external.

In the tested configuration, the stacks have a nominal power of $6.25 \mathrm{~kW}_{\mathrm{DC}}$ in fuel cell mode. Each stack is sintered and tested individually prior to its assembly into the LSM. During qualification, the stack is tested for performance and homogeneity up to $85 \%$ of fuel utilization. Despite having a 4-fold active area with regards to its current commercial counterpart, the capacity to operate at high fuel conversion remains intact, attested by the efficiency and power density that remain the same under equivalent conditions.

The high temperature enclosure in which the stacks are installed serves for the process air distribution among the four stacks. In addition, two collectors ensure a near-equal distribution of fuel among the stacks. Indeed, the distribution of both inlet streams to individual stacks has been designed by CFD to ensure a maximum flowrate deviation of $\pm 2 \%$ on the air side and $\pm 1 \%$ on the fuel side.

Thermal interactions between the stacks are limited by appropriate insulation.

Each stack is equipped with two K-type thermocouples on the air side (air inlet \& outlet) for individual control and two thermocouples in the fuel ports for monitoring. Additionally, the 
LSM is equipped with four thermocouples and pressure sensors located in the inlet and outlet ports.

Each stack has individual current collectors, which allows for control adjustments. Voltage probes at the stack terminals are further used for monitoring and safety.

Aiming for an easy and safe integration of multiple systems in an industrial environment, the LSM comprises an outer enclosure and a ventilation system.

The outer insulation allows limiting the heat losses to the surroundings to less than $2 \mathrm{~kW}$ according to thermal balance calculations.

The LSM used for the electrolysis tests at CEA is based on the very first G8X stacks coming out of the prototyping line, with some known imperfections due to a manufacturing process under optimization. This LSM was first tested in fuel cell mode at DLR Stuttgart where it was able to reach the design point of $25 \mathrm{~kW}_{\mathrm{DC}}$ [27] and later shipped and installed at CEA-Liten in Grenoble.

During the test at DLR, a small crossover had been detected on the second of the four stacks, resulting in a slight heat generation, but with minor impact on its performance. The LSM had also experienced one emergency shutdown under protective conditions at the end of this initial testing campaign, but it was expected that it would operate correctly in the follow-up test at CEA. 


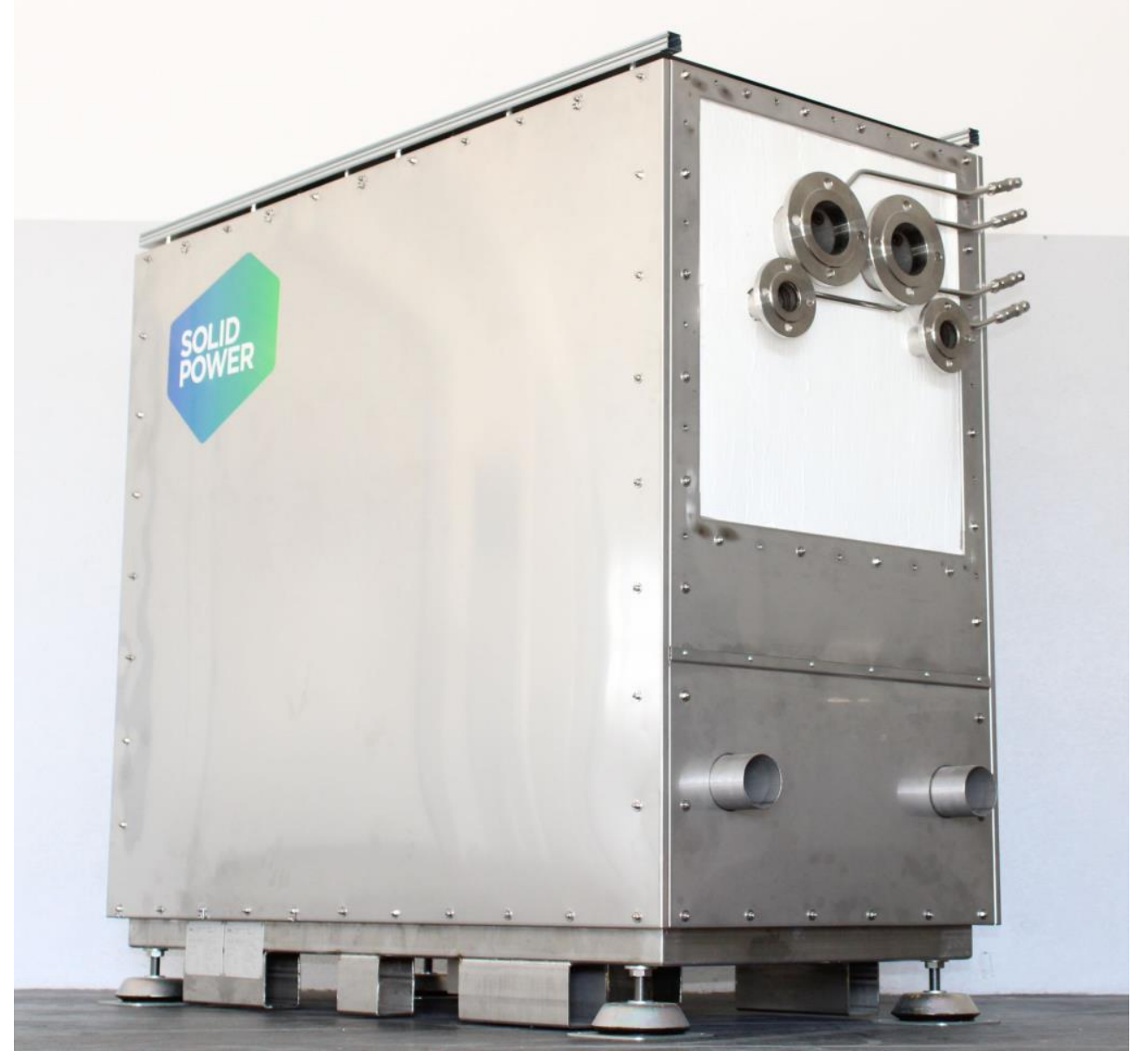

Figure 1: Picture of the Large Stack Module (LSM) by SOLIDpower.

\subsection{The Multistack Testing Platform}

In an effort to test modules and systems of higher power while promoting partnerships, CEALiten is now equipped with the Multistack testing platform. Its dedicated $630 \mathrm{~A}$ three-phase power supply currently allows investigating reversible SOC modules of up to $120 \mathrm{~kW}$ DC power. A Process Flow Diagram (PFD) of the platform is given in Figure 2, and a picture of the final installation in Figure 3. Downstream components and pipe diameters were chosen to keep pressure levels at the test module outlet below 30 mbarg at all time, as per SOLIDpower specification. 


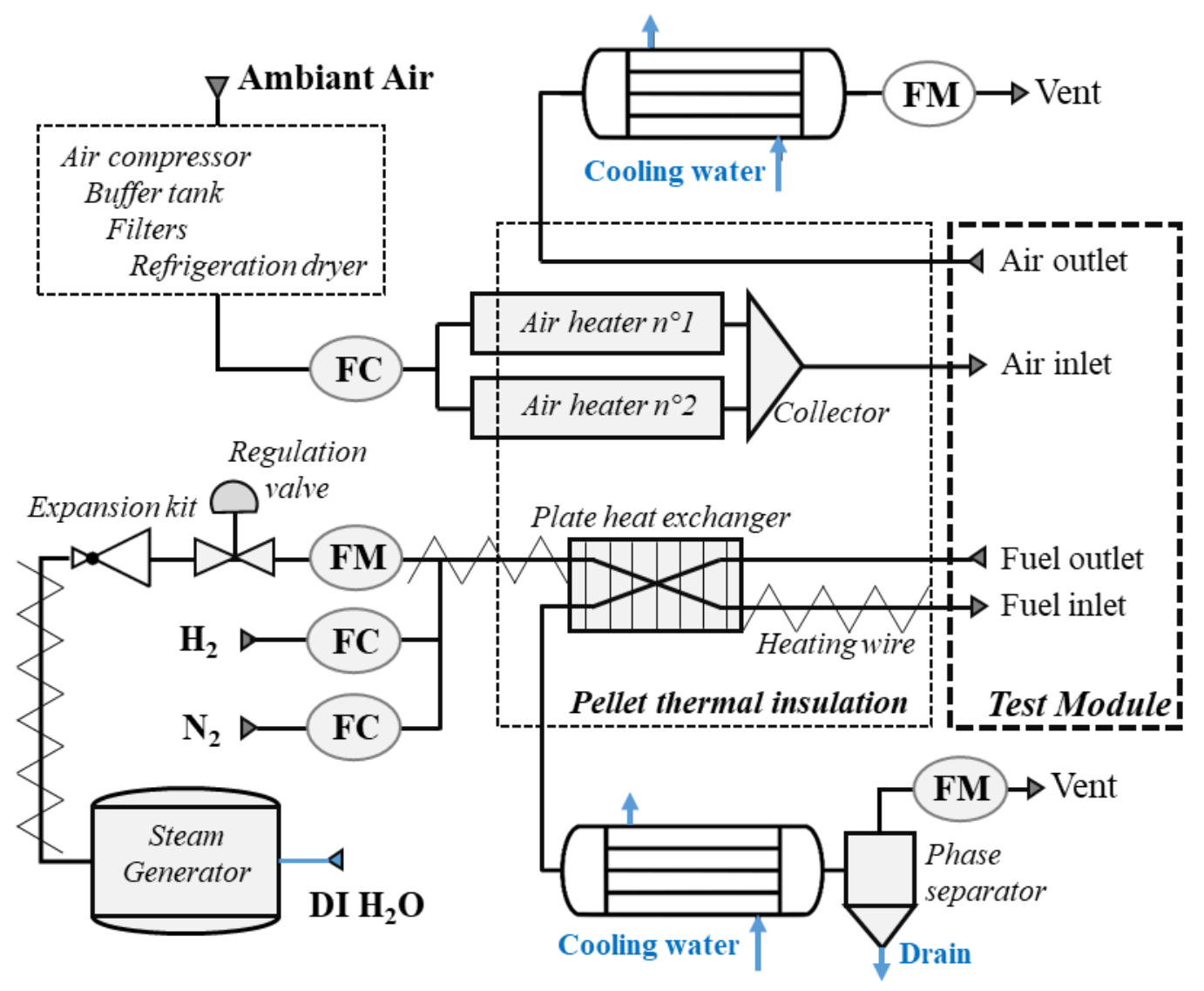

Figure 2: Process Flow Diagram (PFD) of the Multistack testing platform in LSM configuration (FC: Flow Control, FM: Flow Measurement).

Steam was generated using a commercial $60 \mathrm{~kW}$ stainless-steel generator (SG - MA60, Aura Industries) fed by the laboratory deionized water network. Steam pressure was regulated around 8.5 bars inside a tank via two electrical resistances. An expansion kit, placed at the SG outlet, brought the pressure down to about 3 bars. Flow control was then performed on the steam flowrate through a combination of a high temperature analogic electro-pneumatic valve (GX, Emerson) and a vortex flowmeter (8800DR010, Emerson). Mass flow controllers (SLA5863SB, Brooks) were installed on the $\mathrm{H}_{2}$ and $\mathrm{N}_{2}$ building 8 bars supply lines. While both controllers could technically handle flowrates up to $400 \mathrm{NL} \mathrm{min}^{-1}$, experience showed that for $\mathrm{H}_{2}$ flowrates greater than $125 \mathrm{NL} \mathrm{min}^{-1}$, the room feedline pressure collapsed. In consequence, maximum usable $\mathrm{H}_{2}$ flowrate was set to $100 \mathrm{NL} \mathrm{min}^{-1}$. The fuel line was equipped with a plated heat exchanger in counter-flow configuration for heat recovery. A $1.25 \mathrm{~kW}$ heating cord wrapped 
around the pipes insured no condensation occurred between the steam generator and the heat exchanger, in particular where the $\mathrm{N}_{2}$ and $\mathrm{H}_{2}$ merged into the steam line. A $2 \mathrm{~kW}$ hightemperature heating cord was rolled around the pipe linking the cold outlet of the heat exchanger to the fuel inlet of the test module. Its fuel outlet was connected to a tubes \& shell heat exchanger (K-series, Euro Transfert) fed with cold water to cool down gases and condensate steam, and then to an in-house designed separator equipped with a drain trap. Such equipment mechanically directs condensates to the drain while maintaining the tightness of the fuel line. Finally, the cool dry gas outlet flowrate was measured (Whisper, Alicat) before venting it out through a dedicated vent pipe (DN65).

A dedicated $22 \mathrm{~kW}$ air compressor (approximately $3500 \mathrm{NL} \min ^{-1}$ maximum flowrate at 8 bar), buffer tank, refrigeration dryer, and multiple filters supplied the process air. The airflow, regulated via mass flow controller (MCRH, Alicat), fed two $30 \mathrm{~kW}$ preheaters installed in parallel but individually controlled (SureHeat Max-HT, Tutco). The devices were equipped with one type- $K$ thermocouple at the air inlet, to detect insufficient airflow, and two thermocouples at the outlet for regulation and safety. A collector gathered both outlets and directed it to the test module. No heat recovery method was installed on the process air circuit. Similarly to the fuel line, the test module air outlet was directed to a tubes $\&$ shell heat exchanger (G-series, Euro Transfert) for cool down. The outlet air flowrate was then measured and vented out through a dedicated vent pipe (DN100). A type-K thermocouple was installed near the volumetric flowmeter (2051 CFCA, Emerson) to account for the temperature effect on gas density.

Limiting heat losses between the air preheaters and the test module was critical. A $316 \mathrm{~L}$ box was therefore built around the air preheaters, plated heat exchanger, and medium to high temperature piping, and filled with granule insulation material vermiculite Granutec-E®. This time efficient approach allowed reaching high-performance thermal insulation around a 
complex setup geometry. Inconel 600 was used for all high temperature pipes, while $316 \mathrm{~L}$ was preferred for those at room and medium temperatures. Sch10S was chosen for all pipes.

Four independently-controlled $30 \mathrm{~kW}$ reversible power supplies (PSB10200-420, Elektro Automatik) supplied direct current to the stacks. All and only stack voltages were assessed, both via the power supplies (measurements then included losses in the distribution cables), and via direct voltage sensors attached to the stacks end plates. In this last case, stack voltages were converted into a 0-10 V signal before recording via 40-120 V analog converters (CAL23DTHV, Loreme). Consequently, voltages below $40 \mathrm{~V}$ could not be assessed by this method.

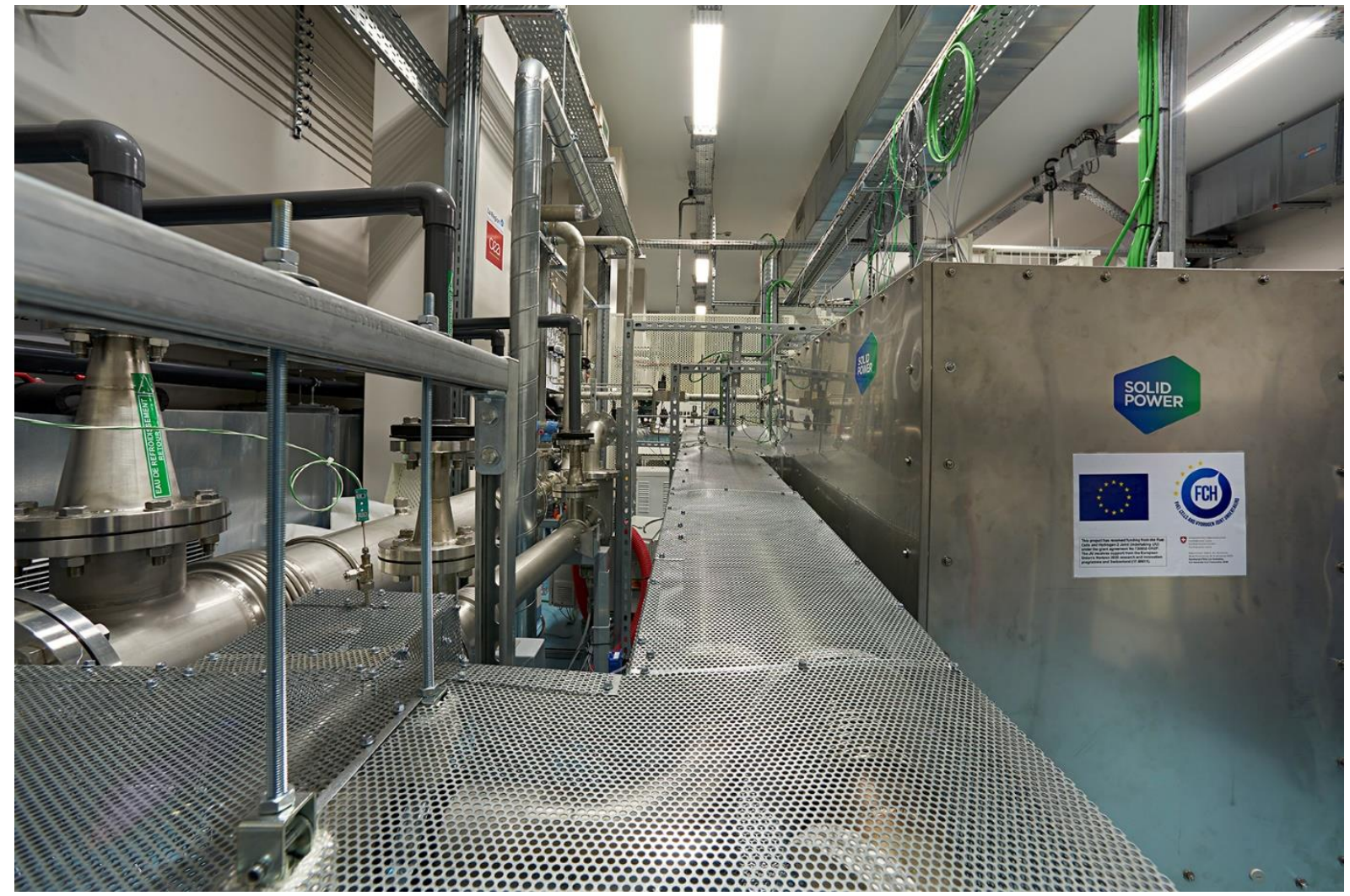

Figure 3: Picture of the Multistack testing platform in LSM configuration (@ D. Guillaudin for CEA) [34]. 


\subsection{Measurements}

Temperature ramps were carried out in air on the $\mathrm{O}_{2}$ electrode side and a mixture of $\mathrm{N}_{2}$ and $\mathrm{H}_{2}$ to prevent $\mathrm{Ni}$ oxidation on the $\mathrm{H}_{2}$ electrode side. The ramp rate was comprised between 0.5 and $0.75{ }^{\circ} \mathrm{C} \mathrm{min}-1$ approximately. Power ramps and polarization curves were typically recorded simultaneously on all stacks (i.e. same current set points on the 4 power supplies through software link). Current ramp rates were $1 \mathrm{~A} \mathrm{~s}^{-1}$ in SOFC mode, and $5 \mathrm{~A} \mathrm{~s}^{-1}$ in SOEC mode. This particularly high last value was chosen to avoid endothermal regime that would have strongly modified the temperature fields in the stacks.

Thermoneutral operation was targeted in SOEC mode, and was assessed through comparison between inlet and outlet airflow temperatures at the stacks level. While thermoneutral voltage is strictly given by thermodynamic calculations (approximately $1.28 \mathrm{~V}$ at $800^{\circ} \mathrm{C}[1]$ ), thermoneutral operation of the LSM was achieved at a higher voltage at which the heat generated by the irreversibilities of the electrochemical processes compensated both the endothermicity of the electrolysis reaction and the heat losses of the module. However, the tradeoff of raising the cell voltage remains a decrease of the DC power-to- $\mathrm{H}_{2}$ efficiency [1]. For a set of operating conditions (flowrates and air inlet temperature), the thermoneutral current, which resulted in thermoneutral operation, was determined by first ramping up the current to approximately $1.295 \mathrm{~V}$ average LSM cell voltage, followed by small adjustments until stabilization of the airflow temperatures. Due to the rapid current ramp in SOEC operation, this process was rather quick.

In order to validate operating conditions and control over the steam supply, timed steam condensate samples were collected from the phase separator (Figure 2) and weighted. Measurements were conducted both at Open Circuit Voltage (OCV) and under load in operation. 


\section{Results and Discussion}

\subsection{Heat Up Process}

Figure 4 displays time evolutions of stack air temperatures, air temperature differences between stacks inlet and outlet, flowrates, fuel cell stack current and measured temperature ramp rate during the heat up process of the LSM. The heating sequence was started at a rate of $0.5^{\circ} \mathrm{C} . \mathrm{min}^{-}$

${ }^{1}$ from ambient temperature to $500^{\circ} \mathrm{C}$. Gas conditions were 3000,250 , and $25 \mathrm{NL} \mathrm{min}^{-1}$ of air, $\mathrm{N}_{2}$ and $\mathrm{H}_{2}$, respectively. Gas temperature differences at the stack level steadily increased, up to $55^{\circ} \mathrm{C}$ for stack ${ }^{\circ} 3(\mathrm{~S} 3)$. A subsequent 4 h steady temperature step was then implemented to allow homogenizing the temperature fields, as evidenced by the decreasing temperature differences between stacks inlet and outlet. Heat-up then resumed at a rate of $0.75{ }^{\circ} \mathrm{C} \cdot \mathrm{min}^{-1}$, which led to temperature differences of up to $80^{\circ} \mathrm{C}$. Unsurprisingly, the temperature ramp rate had a direct impact on gradients. When stack temperatures reached the $\mathrm{H}_{2}$ auto-ignition temperature, the $\mathrm{H}_{2}$ flowrate was increased to $50 \mathrm{NL} \mathrm{min}^{-1}$. Finally, the stacks were polarized in SOFC- $\mathrm{H}_{2}$ mode to accelerate the heat up process and speed up the stabilization of temperature gradients, as showed in Figure 4. 

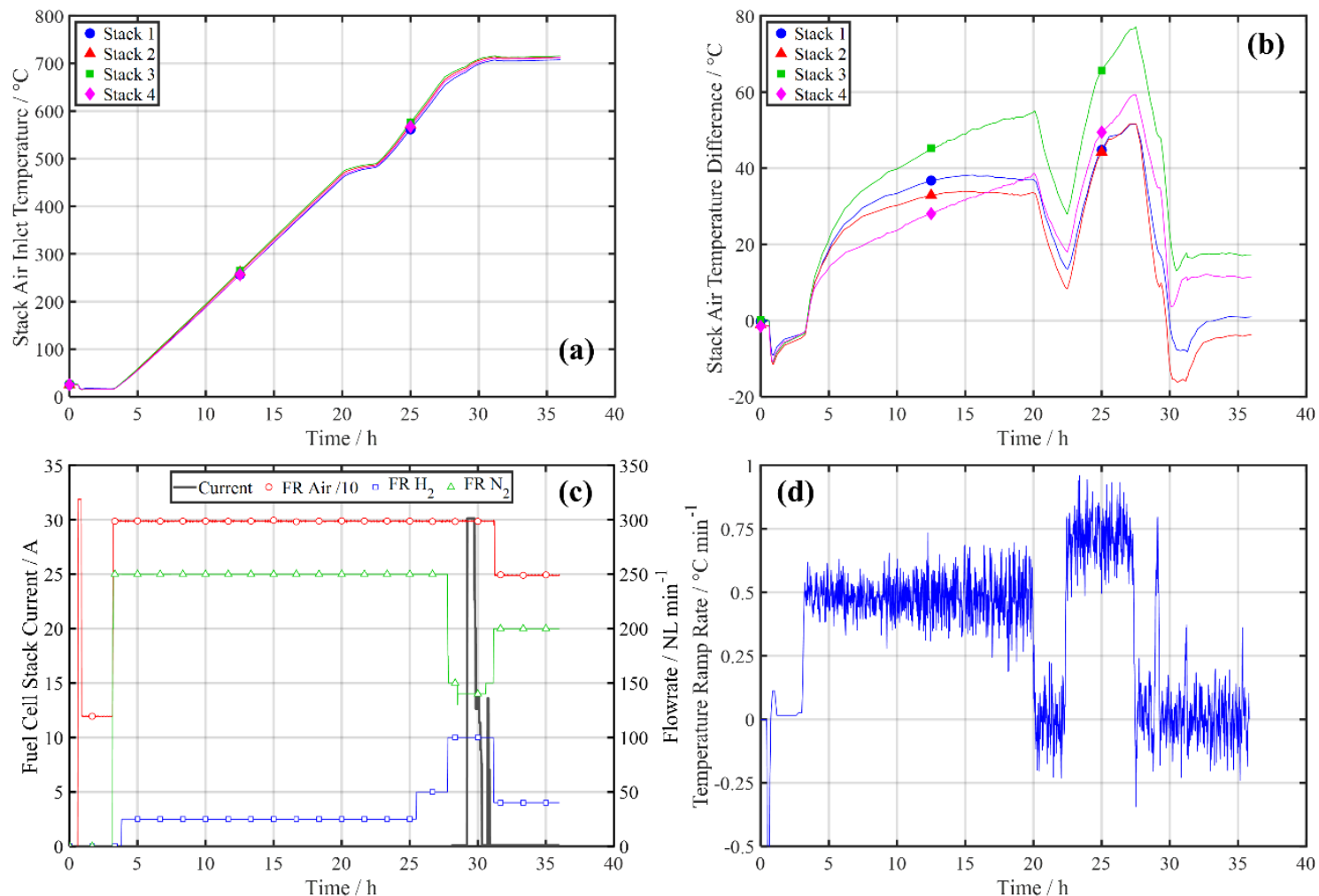

Figure 4: Time evolutions during the LSM heat up process: (a) stack inlet air temperatures, (b) stacks air temperature differences between inlet and outlet, (c) fuel cell stack current and flowrates, (d) measured temperature ramp rate.

Overall, the startup procedure lasted approximately $30 \mathrm{~h}$, and good thermal homogeneity was evidenced. Indeed, all stacks behaved very similarly and the temperature difference between equivalent sensors was less than $25^{\circ} \mathrm{C}$ at all time. While the objective was not here to shorten the heat-up procedure, this un-optimized duration was mostly a consequence of the heating method. The ramp rate was slowed down so that the fragile electrode-supported SOC were not subjected to a temperature difference between air inlet and outlet that could have been damaging. Nevertheless, a $30 \mathrm{~h}$ heat-up procedure is not expected to significantly and negatively affect the "Levelized Cost of Hydrogen" [35] of future industrial plants, likely expected to operate upward of $8,000 \mathrm{~h}$ year $^{-1}$ to offset their CAPEX. 
From a technical standpoint, the results presented in this section allowed validating the air preheating solution for LSM thermal control, and to some extent, the air distribution throughout the module.

\subsection{Open Circuit Voltages in Operation}

The stacks OCVs were measured in different $\mathrm{H}_{2} \mathrm{O} / \mathrm{H}_{2}$ conditions of partial pressures and flowrates at $710^{\circ} \mathrm{C}$. Presented in Table 1 , results remained quite close to the calculated values, reflecting adequate flow control of the steam supply. Unsurprisingly, deviations to theory decrease with higher steam flowrates. Indeed, the steam regulation valve had been specified for a $40 \mathrm{~kg} \mathrm{~h}^{-1}$ nominal flowrate, which is significantly higher than the lower flowrates investigated here. Stacks 3 and 4 (S3 and S4) displayed consistent results throughout the measurements, evidencing near identical gas composition in both and therefore tightness level. Lower values of OCV were recorded on S2, consistent with a small crossover between anodic and cathodic compartments. OCVs of stack $n^{\circ} 1$ were higher than those of $\mathrm{S} 2$, yet slightly lower than $\mathrm{S} 3$ and S4. This would again be consistent with some crossover, albeit smaller than what was evidenced on $\mathrm{S} 2$.

\begin{tabular}{|c|c|c|c|c|c|c|c|c|c|c|}
\hline $\mathbf{F}\left(\mathbf{H}_{2} \mathbf{O}\right)$ & $\mathbf{F}\left(\mathbf{H}_{2}\right)$ & $\mathbf{P}\left(\mathbf{H}_{2} \mathbf{O}\right)$ & $\mathbf{P}\left(\mathbf{H}_{2}\right)$ & $\mathbf{F}_{\text {TOT }}$ & $\mathrm{OCV}_{\text {th }}$ & $\mathrm{OCV}_{\mathrm{S} 1}$ & $\mathrm{OCV}_{\mathrm{S} 2}$ & $\mathrm{OCV}_{\mathrm{S3}}$ & $\mathrm{OCV}_{\mathrm{S4}}$ & $\Delta$ \\
\hline$/ \mathrm{kg} \mathrm{h}^{-1}$ & / NL $\min ^{-1}$ & \multicolumn{2}{|c|}{ / vol\% } & 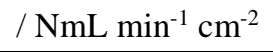 & & & $/ \mathrm{mV}$ & & & $1 \%$ \\
\hline 6 & 100 & $55.5 \%$ & $44.5 \%$ & 2.92 & 961 & 943 & 937 & 947 & 948 & $-1.8 \%$ \\
\hline 10 & 100 & $67.5 \%$ & $32.5 \%$ & 4 & 939 & 926 & 919 & 929 & 930 & $-1.4 \%$ \\
\hline 15 & 100 & $75.7 \%$ & $24.3 \%$ & 5.36 & 922 & 910 & 904 & 914 & 914 & $-1.2 \%$ \\
\hline 20 & 100 & $80.6 \%$ & $19.4 \%$ & 6.71 & 910 & 900 & 894 & 903 & 904 & $-1.0 \%$ \\
\hline 22.2 & 75 & $86.0 \%$ & $14.0 \%$ & 6.98 & 893 & 885 & 878 & 887 & 888 & $-1.0 \%$ \\
\hline 22.2 & 51.2 & $90.0 \%$ & $10.0 \%$ & 6.67 & 877 & 869 & 863 & 872 & 873 & $-0.9 \%$ \\
\hline
\end{tabular}

Table 1: Stacks OCVs in different $\mathrm{H}_{2} \mathrm{O} / \mathrm{H}_{2}$ mixtures and flowrates at $710^{\circ} \mathrm{C} . \Delta$ is the relative deviation between the average experimental OCV (for stacks $\mathrm{S} 1$ to $\mathrm{S} 4)$ and the theory $\left(\mathrm{OCV}_{\mathrm{th}}\right)$. 


\subsection{Initial Polarization Curves}

Due to the somewhat limited $\mathrm{H}_{2}$ supply, part-load polarization curves in SOFC- $\mathrm{H}_{2}$ mode were recorded, corresponding to $100+150 \mathrm{NL} \min ^{-1} \mathrm{H}_{2}+\mathrm{N}_{2}$ flowrates. Figure 5 shows the initial performances up to $54 \mathrm{~A}$, or $90 \%$ Fuel Utilization (FU). The OCV distribution in dry $\mathrm{H}_{2}$, a strong indicator of stacks tightness level, further confirmed the observations of the previous section. The high FU was targeted to investigate fuel distribution over the four stacks, and excellent results were evidenced. Indeed, the four stacks behaved near identically, and the slightly lower S2 voltage can be explained by an effective FU higher than the theoretical one due to a crossover likely located somewhat upstream of to the fuel outlet. This would also explain the slight limiting current on this stack, not or hardly visible on the other three.

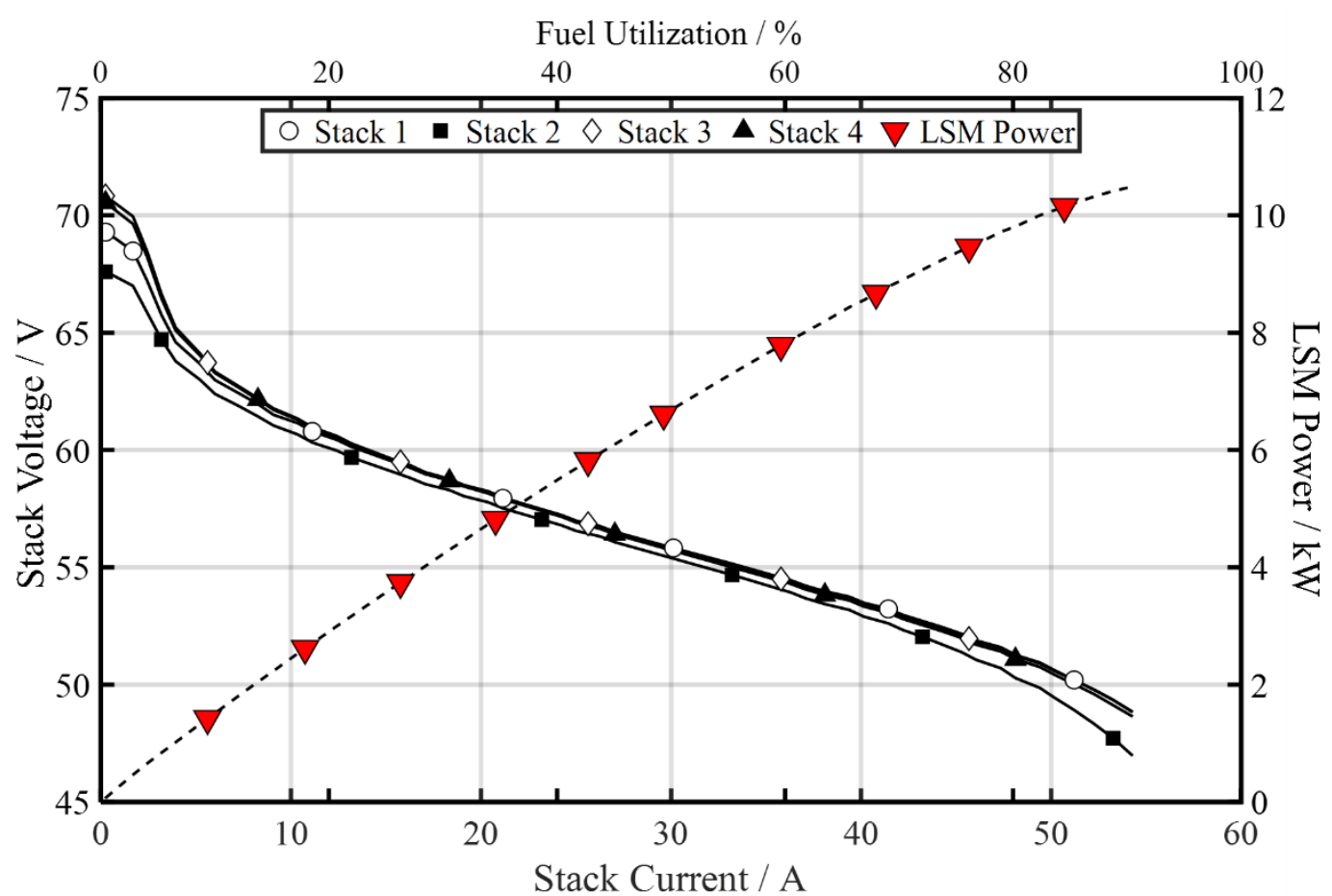

Figure 5: Initial performances in part load SOFC- $\mathrm{H}_{2}$ mode. Polarization curves recorded simultaneously on all stacks in $100+150 \mathrm{NL} \min ^{-1} \mathrm{H}_{2}+\mathrm{N}_{2}$ at $710^{\circ} \mathrm{C}$.

Figure 6 shows a performance curve in SOEC mode, as recorded during a transient state from thermoneutral operation to OCV. The stacks outlet air temperatures were then approximately 
$740^{\circ} \mathrm{C}$. Due to the chosen current ramp rate of $5 \mathrm{~A} \mathrm{~s}^{-1}$, the corresponding power ramp rate was here in the range of $2 \mathrm{~kW}_{\mathrm{DC} \mathrm{s}}{ }^{-1}$. In these conditions, the thermoneutral current and corresponding LSM power were -217 A and $68 \mathrm{~kW}$, respectively. During the ramp down, stack voltage dispersion was again limited, in particular when excluding S2. The crossover previously identified led in this case to both a higher operating stack temperature and a lower Steam Conversion (SC), therefore resulting in a lower voltage compared to the other stacks.

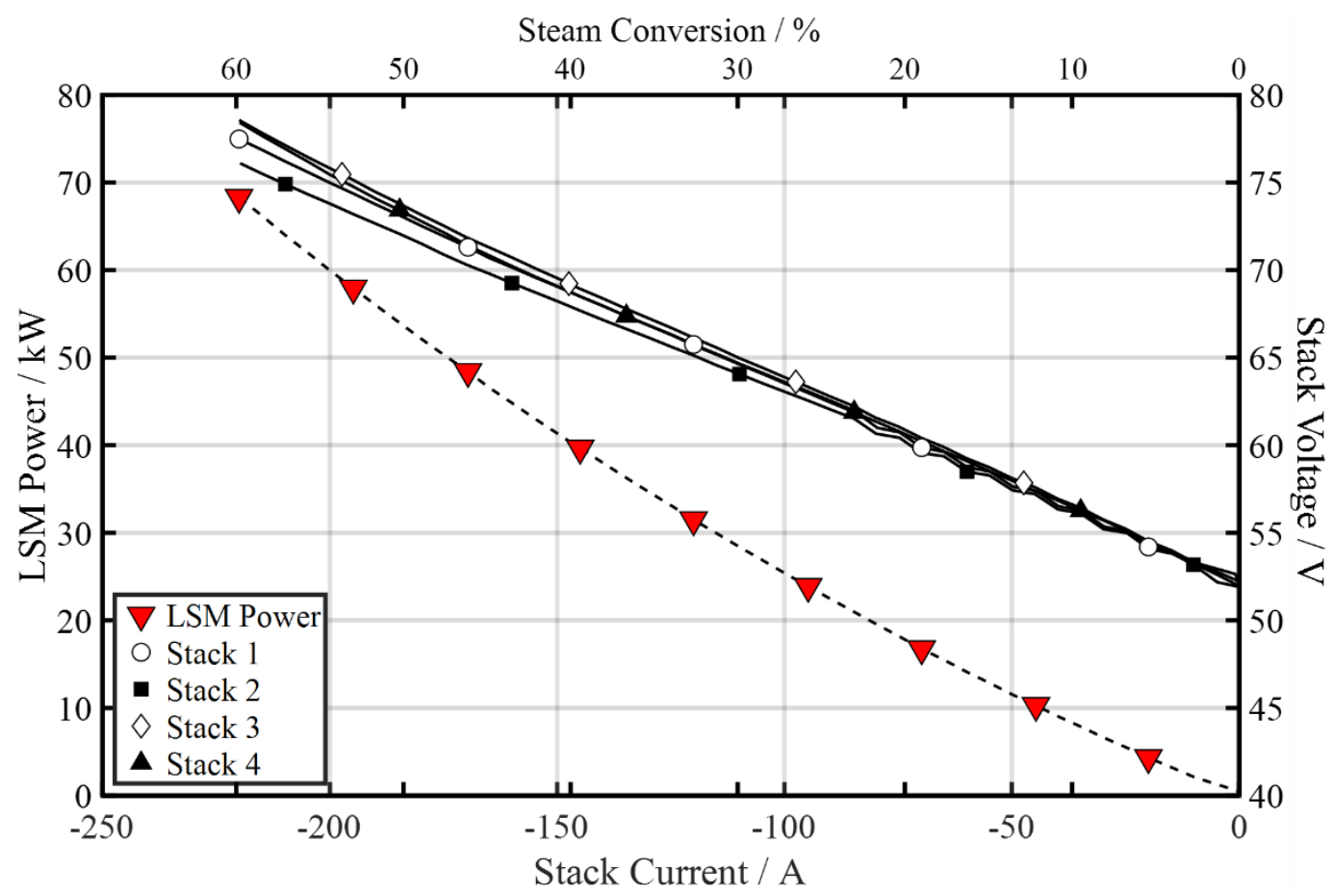

Figure 6: Example of performances in SOEC mode. Polarization curves recorded simultaneously on all stacks in 8.9 $\mathrm{NmL} \mathrm{m^{-1 }} \mathrm{cm}^{-2} 90 / 10 \mathrm{vol} \% \mathrm{H}_{2} \mathrm{O} / \mathrm{H}_{2}$, or $8 \mathrm{NmL} \mathrm{min}^{-1} \mathrm{~cm}^{-2} \mathrm{H}_{2} \mathrm{O}$, at approximately $740^{\circ} \mathrm{C}$. Steam conversion is reported on the secondary $\mathrm{X}$-axis.

To validate further the control over the steam supply, a condensate collection measurement was carried out at OCV and under polarization. Experimental conditions and results are presented in Table 2. The measurements yielded reassuring deviations within 3\% of expected condensate flowrates.

\begin{tabular}{llllllll}
\hline $\boldsymbol{F}\left(\mathrm{H}_{2} \mathrm{O}\right)$ & $I$ & $\mathrm{SC}$ & $V_{\text {sample }}$ & Collection time & $\mathrm{CF}_{\text {calc }}$ & $\mathrm{CF}_{\exp }$ & $\Delta$
\end{tabular}




\begin{tabular}{cccccccc}
$/ \mathrm{kg} \mathrm{h}^{-1}$ & $/ \mathrm{A}$ & $/ \%$ & $/ \mathrm{L}$ & $/ \mathrm{s}$ & \multicolumn{2}{c}{$/ \mathrm{kg} \mathrm{h}^{-1}$} & $/ \%$ \\
\hline \multirow{2}{*}{22.2} & 0 & 0 & \multirow{2}{*}{4} & 640 & 22.2 & 22.5 & $1.4 \%$ \\
& 175 & 69.1 & & 1840 & 8.04 & 7.83 & $-2.7 \%$ \\
\hline
\end{tabular}

Table 2: Condensate collection measurement at OCV and under polarization. CF refers to condensate flowrate.

\subsection{Thermal Balances}

After a night of thermal stabilization at $\mathrm{OCV}$, inlet and outlet gas temperatures were recorded to perform heat balances and evaluate thermal losses. This was done twice with two distinct sets of gas flowrates and compositions (Table 3). Heat capacities were calculated based on data from both references [36] and [37]. The following Table 4 gathers the results of the calculations.

\begin{tabular}{ccccc}
\hline ID & $\begin{array}{c}\boldsymbol{F}\left(\mathbf{H}_{2} \mathbf{O}\right) \\
/ \mathrm{kg} \mathrm{h}^{-1}\end{array}$ & $\begin{array}{c}\boldsymbol{F}\left(\mathbf{H}_{2}\right) \\
/ \mathrm{NL} \mathrm{min}^{-1}\end{array}$ & $\begin{array}{c}\boldsymbol{F}\left(\mathbf{N}_{2}\right) \\
/ \mathrm{NL} \mathrm{min}^{-1}\end{array}$ & $\begin{array}{c}\boldsymbol{F}(\mathbf{A i r}) \\
/ \mathrm{NL} \mathrm{min}^{-1}\end{array}$ \\
\hline $\mathrm{C} 1$ & 0 & 40 & 200 & 2200 \\
$\mathrm{C} 2$ & 22.2 & 51.2 & 0 & 2800 \\
\hline \multicolumn{2}{r}{ Table 3: Gas conditions used for heat losses assessments. }
\end{tabular}

\begin{tabular}{lccccccc}
\hline ID & \multirow{2}{*}{ Ref. } & \multirow{2}{*}{ Boundary } & $\begin{array}{c}\text { F.I. } \\
/ \mathrm{kW}\end{array}$ & $\begin{array}{c}\text { F.O. } \\
/ \mathrm{kW}\end{array}$ & $\begin{array}{c}\text { A.I. } \\
/ \mathrm{kW}\end{array}$ & $\begin{array}{c}\text { A.O. } \\
/ \mathrm{kW}\end{array}$ & $\begin{array}{c}\text { Balance } \\
/ \mathrm{kW}\end{array}$ \\
\hline C1 & {$[36]$} & & 3.55 & 4.13 & 41.41 & 39.77 & -1.06 \\
$\mathrm{C} 1$ & {$[37]$} & LSM & 3.55 & 4.13 & 41.48 & 39.81 & -1.09 \\
C2 & {$[36]$} & & 9.20 & 10.56 & 50.90 & 48.76 & -0.78 \\
C2 & {$[37]$} & & 9.30 & 10.64 & 50.95 & 48.79 & -0.83 \\
\hline C1 & & Stack 1 & 3.97 & 4.08 & 39.87 & 39.86 & 0.10 \\
C1 & & Stack 2 & 4.06 & 4.16 & 40.32 & 40.62 & 0.39 \\
C1 & & Stack 3 & 4.14 & 4.02 & 40.29 & 39.74 & -0.67 \\
C1 & {$[36]$} & Stack 4 & 4.11 & 4.07 & 40.50 & 39.60 & -0.94 \\
C2 & Stack 1 & 9.94 & 10.43 & 48.76 & 48.41 & 0.14 \\
C2 & & Stack 2 & 10.19 & 10.68 & 49.29 & 49.24 & 0.45 \\
C2 & & Stack 3 & 10.57 & 10.52 & 49.42 & 48.78 & -0.69 \\
C2 & & Stack 4 & 10.39 & 10.55 & 49.61 & 48.53 & -0.91 \\
\hline
\end{tabular}

Table 4: Heat losses assessments at the LSM and individual stacks levels. F. and A. refer to Fuel and Air, while I. and O. refer to Inlet and Outlet.

Both methods of calculation led to similar results, with a limited global heat loss at the LSM level comprised between 0.8 and $1.1 \mathrm{~kW}$ depending on the gas conditions investigated. As the fuel inlet flow temperature is lower than that of the inlet air and therefore of the LSM, the fuel 
heated up so that the energy balance of the fuel line was positive. It should be noted that due to the small crossover exhibited mainly by S2, heat losses are underestimated to some extent. Accordingly, a fraction of the total air flow would have benefited from heat generated by internal combustion. The calculations are based on the hypothesis that the inlet flows are perfectly distributed between all stacks, which has been mainly validated for the fuel side.

Using Todd \& Young [36] heat capacities calculation method only, heat balances were also carried out at the stacks level for both sets of gas conditions. The results are also presented in Table 4 and show an uneven distribution of heat losses amongst stacks: stack $n^{\circ} 1$ displays nearadiabatic behavior, while the most significant heat loss occurs at the stack $\mathrm{n}^{\circ} 4$ level. This observation most likely stems from the LSM design, where the stacks are lined up one behind the other in regards to the flows distribution, leading to small differences in thermal fields.

\subsection{Pressure Drops}

The following Table 5 gathers data related to LSM pressure drops in different experimental conditions of flowrates and temperature. The recorded pressure drop on the air side was quite

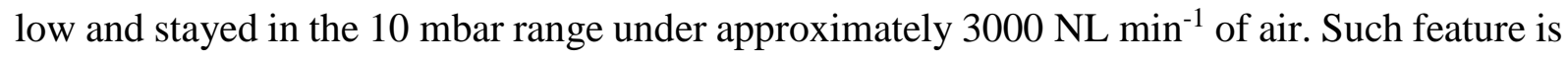
particularly suitable for heat management in SOFC operation, and thermally homogeneous start-up processes since the LSM was heated through hot air. Regarding the fuel compartment, the pressure drop increased up to 30 mbar under higher steam flowrate, and dropped down below 10 mbar under part-load SOFC- $\mathrm{H}_{2}$ operation. As already mentioned, in this last condition, despite the low pressure drop, an impressive 90\% FU could be achieved at the module level. 


\begin{tabular}{|c|c|c|c|c|c|c|c|}
\hline $\mathbf{F ( A i r )}$ & $\begin{array}{l}\mathbf{F}\left(\mathbf{N}_{2}\right) \\
\text { LL mir }\end{array}$ & $\mathbf{F}\left(\mathbf{H}_{2}\right)$ & $\begin{array}{l}\mathbf{F}\left(\mathbf{H}_{2} \mathbf{O}\right) \\
/ \mathrm{kg} \mathrm{h}^{-1}\end{array}$ & $\begin{array}{c}\mathbf{T}_{\text {Air,IN }} \\
/{ }^{\circ} \mathrm{C}\end{array}$ & $\begin{array}{c}\text { Iaverage } \\
\text { / A }\end{array}$ & $\begin{array}{r}\Delta P_{L S M, f u e l} \\
/ \mathrm{m}\end{array}$ & $\begin{array}{l}\Delta \mathbf{P}_{\text {LSM,air }} \\
\text { jar }\end{array}$ \\
\hline 2988 & 250 & 25.1 & 0.0 & 36 & 0 & 2.1 & 1.5 \\
\hline 2990 & 250 & 25.0 & 0.0 & 400 & 0 & 6.1 & 5.5 \\
\hline 2988 & 250 & 50.0 & 0.0 & 713 & 0 & 11.8 & 9.8 \\
\hline 2790 & 0 & 51.3 & 23.5 & 735 & 0 & 21.7 & 9.6 \\
\hline 2890 & 0 & 68.0 & 25.7 & 734 & 0 & 27.7 & 10.0 \\
\hline 2988 & 0 & 51.2 & 22.9 & 768 & 0 & 23.9 & 10.2 \\
\hline 2986 & 0 & 68.0 & 29.1 & 769 & 230 & 29.7 & 11.0 \\
\hline 2591 & 25 & 25.6 & 11.4 & 708 & 70 & 9.9 & 9.8 \\
\hline 2986 & 140 & 100 & 0.0 & 690 & 0 & 8.6 & 10.1 \\
\hline
\end{tabular}

\subsection{Details on Performance Map Recording}

The following Figure 7 displays time evolutions of LSM power, average stack voltages and air temperatures during a sweep of the 6-to- $8 \mathrm{NmL} \mathrm{min}^{-1} \mathrm{~cm}^{-2}$ (or 22.4-to-29.6 $\mathrm{kg} \mathrm{h}^{-1}$ ) steam flowrates range, while striving to maintain $710^{\circ} \mathrm{C}$ quasi-isothermal operation. For the different flowrates investigated, isothermal currents were assessed by incremental changes to maintain approximately $1.295 \mathrm{~V}$ average cell voltage at the LSM level. During transient states, flowrates and stack currents were modified simultaneously to stabilize voltages. Due to the fast power ramp up, the temperature distribution across the stacks was barely modified by the short-term endothermic operation. Consequently, thermal quasi-equilibrium was reached rather quickly and the measurement sequence only lasted about $3 \mathrm{~h}$. When the LSM had just been polarized, exothermal operation was forced for a few minutes to participate to the stacks heat up process and help homogenizing the temperature fields across all stacks. In these conditions, data recording for the performance map occurred after $1 \mathrm{~h} 58,2 \mathrm{~h} 38$ and $2 \mathrm{~h} 58$.

Results showed that the stacks outlet air temperatures were stable across the three different steam flowrates investigated, highlighting thermal stability through the control strategy. The air outlet temperature difference between $\mathrm{S} 1, \mathrm{~S} 3$ and $\mathrm{S} 4$ was less than $10^{\circ} \mathrm{C}$. The air exiting $\mathrm{S} 2$ was about $15^{\circ} \mathrm{C}$ hotter than the average temperature due to its previously evidenced crossover and 
internal combustion, which impact was exacerbated when large quantities of $\mathrm{H}_{2}$ were produced. This suggested that the crossover was located downstream of the stack inlet in regards to the fuel flow. The average stack outlet air temperature evolved by approximately $+15^{\circ} \mathrm{C}$ between OCV and polarized states, indicating that $1.295 \mathrm{~V}$, while being quite close to the thermodynamic thermoneutral voltage $(1.287 \mathrm{~V})$ at $710^{\circ} \mathrm{C}$, was still higher than the module thermoneutral voltage. This observation is consistent with the calculated small thermal losses of the module as previously reported.
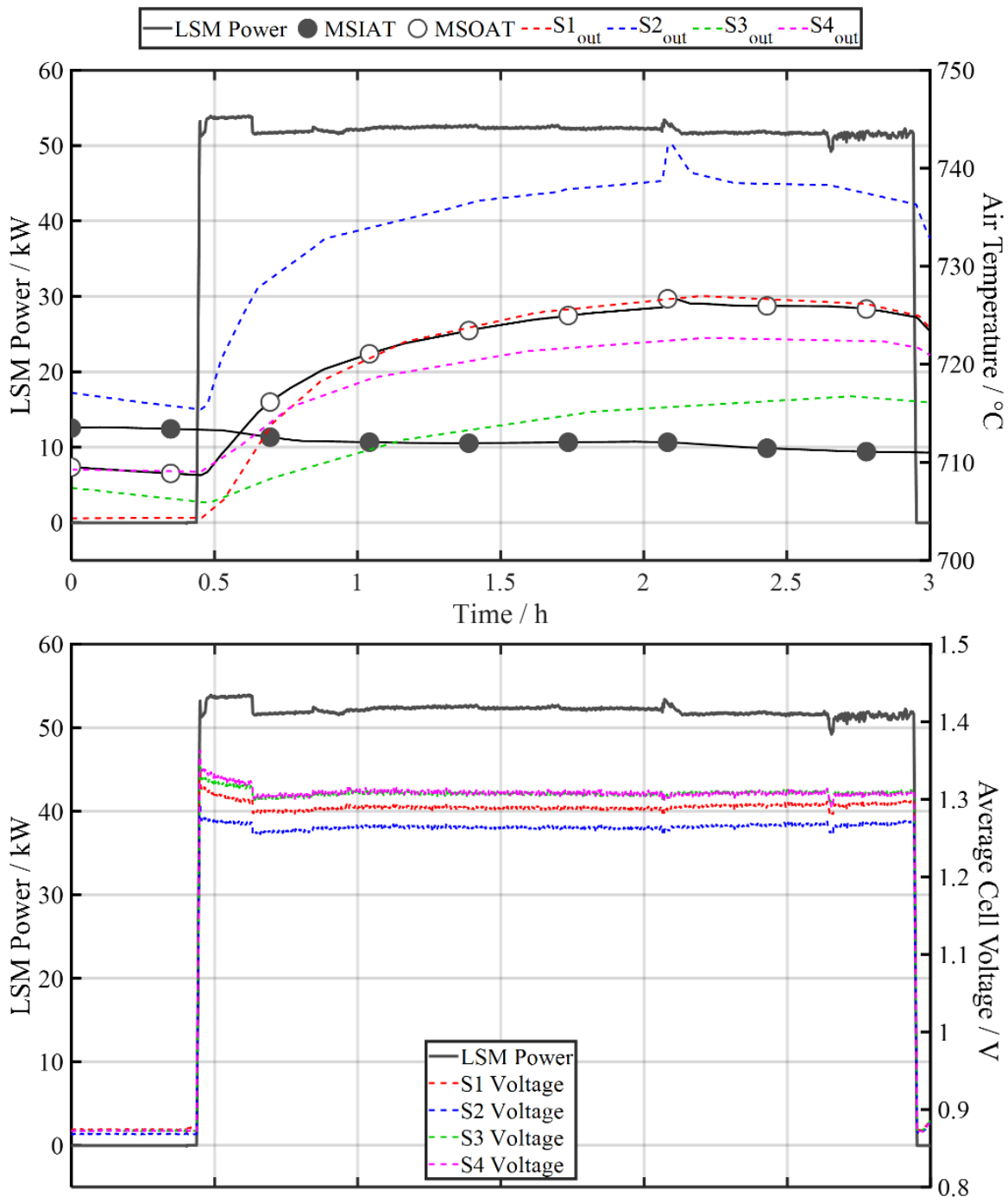

Figure 7: Time evolutions of LSM power, voltages, and air temperatures during a sweep of 6-to-8 NmL min ${ }^{1} \mathrm{~cm}^{-2}$ steam flowrates at approximately $710^{\circ} \mathrm{C}$. MSIAT/MSOAT: mean stack inlet/outlet air temperature. 


\subsection{Performance Map}

The following Table 6 gathers the results of the performance map recordings. The objective was to assess the thermoneutral current at the LSM level following the method described in the previous section, by keeping the voltage constant and modifying the flowrates. Throughout the entire protocol, a maximum deviation of $3 \%$ (average $-0.4 \%$ ) was evidenced between the measured $\mathrm{H}_{2}$ flowrate at the platform outlet and the calculated flowrate from current values using Faraday's law.

\begin{tabular}{|c|c|c|c|c|c|c|c|c|c|c|c|}
\hline $\begin{array}{l}\mathbf{F}\left(\mathbf{H}_{2} \mathbf{O}\right) \\
/ \mathrm{kg} \mathrm{h}^{-1} \\
\end{array}$ & $\begin{array}{c}\mathbf{F}\left(\mathbf{H}_{2}\right) \\
/ \mathrm{NL}\end{array}$ & $\begin{array}{l}\text { F(air) } \\
\min ^{-1} \\
\end{array}$ & $\begin{array}{c}\text { MSIAT } \\
/{ }^{\circ} \mathrm{C} \\
\end{array}$ & $\begin{array}{c}I \\
/ \mathrm{A}\end{array}$ & $\begin{array}{l}\text { SC } \\
1 \% \\
\end{array}$ & $\begin{array}{l}\mathbf{U}_{\text {ave }} \\
/ \mathrm{V} \\
\end{array}$ & $\begin{array}{c}\mathbf{W}_{\text {LSM }} \\
/ \mathrm{kW}_{\mathrm{DC}} \\
\end{array}$ & $\begin{array}{c}\mathbf{F}\left(\mathbf{H}_{2}\right)_{\text {out }} \\
/ \mathrm{NL} \mathrm{min}^{-1} \\
\end{array}$ & $\begin{array}{c}\text { Prod }_{\text {exp }} \\
\quad / \mathrm{kg} \\
\end{array}$ & $\operatorname{Prod}_{\text {th }}$ & $\begin{array}{c}\Delta_{\text {prod }} \\
/ \% \\
\end{array}$ \\
\hline 22.2 & 51.2 & 2800 & 713 & 187 & $67.9 \%$ & 1.292 & 58.0 & 393.7 & 39.2 & 40.2 & $-2.4 \%$ \\
\hline 25.9 & 60 & 2800 & 711 & 194 & $60.4 \%$ & 1.295 & 60.3 & 419.2 & 41.1 & 41.7 & $-1.5 \%$ \\
\hline 29.6 & 68 & 2800 & 711 & 198 & $53.9 \%$ & 1.296 & 61.6 & 439.4 & 42.4 & 42.6 & $-0.3 \%$ \\
\hline 22.2 & 51.2 & 3000 & 722 & 193 & $70.1 \%$ & 1.288 & 59.7 & 404.6 & 0.5 & 1.5 & $-2.4 \%$ \\
\hline 25.9 & 60 & 3000 & 722 & 202 & $62.9 \%$ & 1.292 & 62.6 & 434.5 & 42.8 & 43.4 & $-1.3 \%$ \\
\hline 29.6 & 68 & 3000 & 720 & 208 & $56.6 \%$ & 1.295 & 64.6 & 458.0 & 44.6 & 4.7 & $-0.3 \%$ \\
\hline 22.2 & 51.2 & 3000 & 732 & 203 & $73.7 \%$ & 1.288 & 62.8 & 419.8 & 42.3 & 43.6 & $-3.1 \%$ \\
\hline 25.9 & 60 & 3000 & 731 & 213 & $66.3 \%$ & 1.294 & 66.1 & 455.7 & 45.3 & 45.8 & $-1.0 \%$ \\
\hline 29.6 & 68 & 3000 & 731 & 220 & $59.9 \%$ & 1.295 & 68.4 & 481.2 & 47.3 & 47.3 & $0.0 \%$ \\
\hline 22.2 & 51.2 & 3100 & 745 & 211 & $76.9 \%$ & 1.289 & 65.3 & 440.8 & 44.7 & 45.4 & $-1.4 \%$ \\
\hline 25.9 & 60 & 3100 & 745 & 224 & $69.2 \%$ & 1.296 & 69.7 & 479.8 & 8.1 & 48.1 & $-0.1 \%$ \\
\hline 29.6 & 68 & 3100 & 743 & 231 & $62.9 \%$ & 1.295 & 71.8 & 515.6 & 51.3 & 49.7 & $3.2 \%$ \\
\hline 29.6 & 68 & 3100 & 744 & 237 & $64.5 \%$ & 1.305 & 74.2 & 525.4 & 52.4 & 50.9 & $2.9 \%$ \\
\hline 25.9 & 60 & 3100 & 745 & 230 & $71.6 \%$ & 1.309 & 72.3 & 493.9 & .8 & 49.4 & $0.7 \%$ \\
\hline 22.2 & 51.2 & 3100 & 746 & 218 & $79.1 \%$ & 1.303 & 68.2 & 455.3 & 46.4 & 46.9 & $-1.0 \%$ \\
\hline 22.2 & 51.2 & 2800 & 714 & 185 & $67.2 \%$ & 1.292 & 57.4 & 393.7 & 39.2 & 39.8 & $-1.3 \%$ \\
\hline 25.9 & 60 & 2800 & 714 & 192 & $59.7 \%$ & 1.296 & 59.7 & 421.3 & 41.3 & 41.3 & $0.1 \%$ \\
\hline 29.6 & 68 & 2800 & 712 & 196 & $53.4 \%$ & 1.297 & 61.0 & 441.8 & 42.7 & 42.1 & $1.3 \%$ \\
\hline
\end{tabular}

Table 6: Initial performance map. MSIAT: mean stacks inlet air temperature, I: (near-) thermoneutral current, $\mathrm{SC}$ : calculated steam conversion, $\mathrm{U}_{\text {ave }}$ : average cell voltage of the LSM, Prod ${ }_{\text {exp }} \mathrm{H}_{2}$ production measured via flowmeter, Prod $\mathrm{th}_{\mathrm{th}}$ expected $\mathrm{H}_{2}$ production from current calculations.

At constant temperature and operating voltage, results showed a moderate benefit of an increased steam flow on the hydrogen production, at least in the tested domain. For example, increasing the steam flowrate from 6 to $8 \mathrm{NmL} \mathrm{min}^{-1} \mathrm{~cm}^{-2}(+33 \%)$ led to a decrease of the conversion near the thermoneutral voltage from $74 \%$ to $60 \%$ at $731{ }^{\circ} \mathrm{C}$ and an increase of $\mathrm{H}_{2}$ 
production from 42 to $47 \mathrm{~kg} \mathrm{day}^{-1}(+9 \%)$. A similar trend was previously reported in [21], however to a lower extent. On the other hand, the data shows that the thermoneutral current was more strongly influenced by the stack temperature. At $8 \mathrm{NmL} \mathrm{min}^{-1} \mathrm{~cm}^{-2}$ steam flowrate, a moderate increase of temperature from $712^{\circ} \mathrm{C}$ to $745^{\circ} \mathrm{C}$ lead to an increase of production from 42 to $52 \mathrm{~kg} \mathrm{day}^{-1}(+23 \%)$. Furthermore, at higher temperature, the benefit of an increased steam flowrate on the near-thermoneutral current was somewhat more pronounced. Interesting conversion rates of $80 \%$ were attained at $745^{\circ} \mathrm{C}$ for an output of $46 \mathrm{~kg} \mathrm{day}^{-1}$, showing that further exploration of the operation domain above $750^{\circ} \mathrm{C}$ and at lower steam input would be of interest.
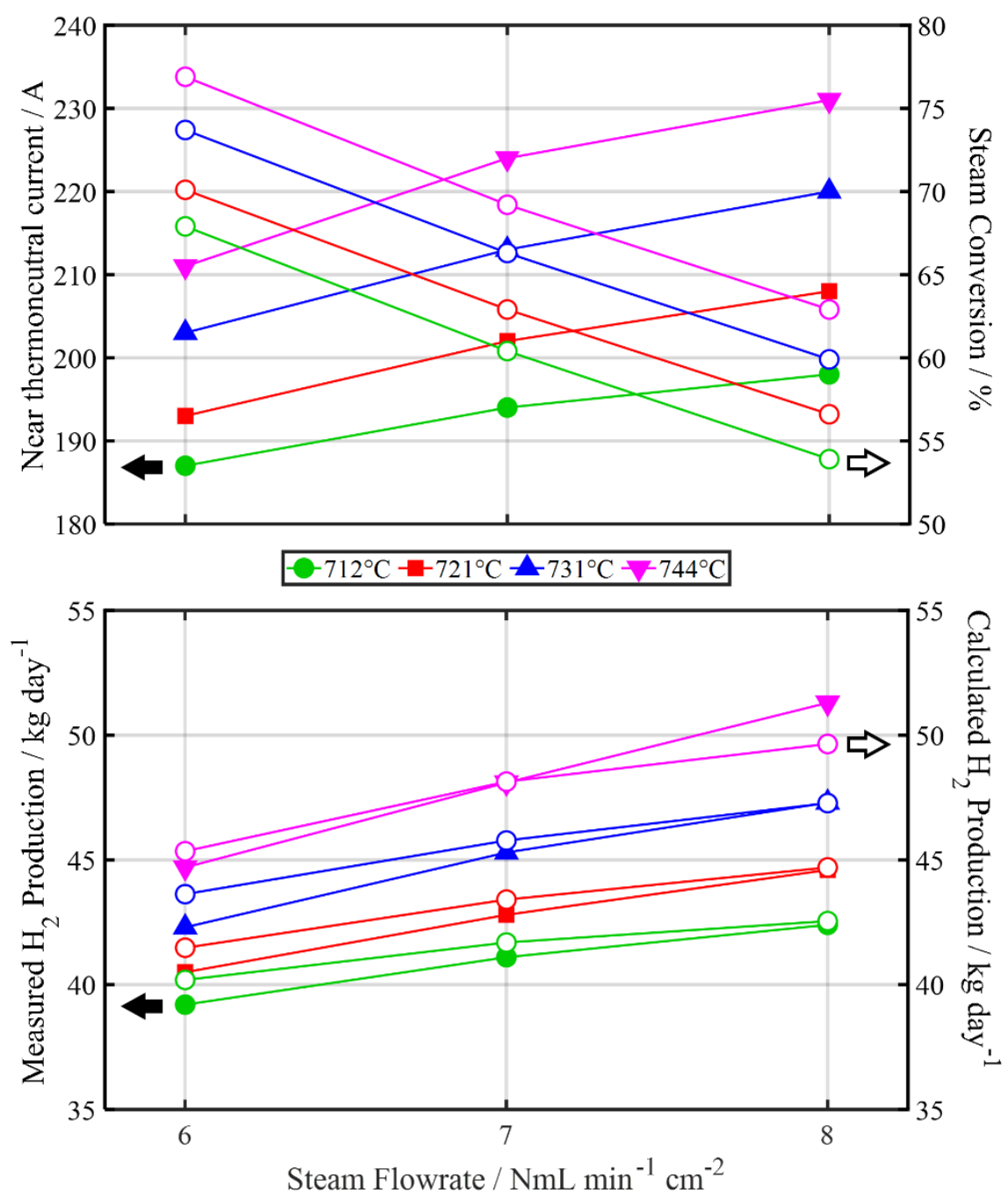

Figure 8: Initial performance map in electrolysis mode. Solid symbols are related to the left y-axis, empty ones to the right. 
A series of three measurements were carried out at $745^{\circ} \mathrm{C}$ to investigate the impact of the operating voltage on the hydrogen production. For three flowrates, currents corresponding to a LSM average cell voltage of approximately $1.305 \mathrm{~V}$ were recorded and compared to those obtained at 1.295 V. Results are shown in Table 6. Limited impact on the current was noted. Indeed, raising the average cell voltage from 1.295 to $1.305 \mathrm{~V}$, approximately, only raised the current by 6-7 A, or 3\%, once again highlighting the stronger impact of temperature over other experimental parameters on stack current. Figure 9 shows the air temperature profiles during the discussed measuring period. Evidently, the system was then not thermally stable, as the average stack outlet air temperature is still seen rising rather quickly when the stacks were returned to OCV. However, part of this increase in air temperatures was due to a $+100 \mathrm{NL}$ min $^{-}$ ${ }^{1}$ air flowrate increase between the recordings at $1.295 \mathrm{~V}$ and $1.305 \mathrm{~V}$, respectively, carrying in more heat from the preheaters. Nevertheless, the data of this performance map can now be used to link temperature, steam conversion, and current $/ \mathrm{H}_{2}$ production rate. At peak power, the LSM converted $74.2 \mathrm{~kW}_{\mathrm{DC}}$ into more than $50 \mathrm{kgH}_{2}$ day $^{-1}$. If part-load operation is of interest, additional measurements could be carried out to extend this performance map towards the lower temperatures and flowrates. 


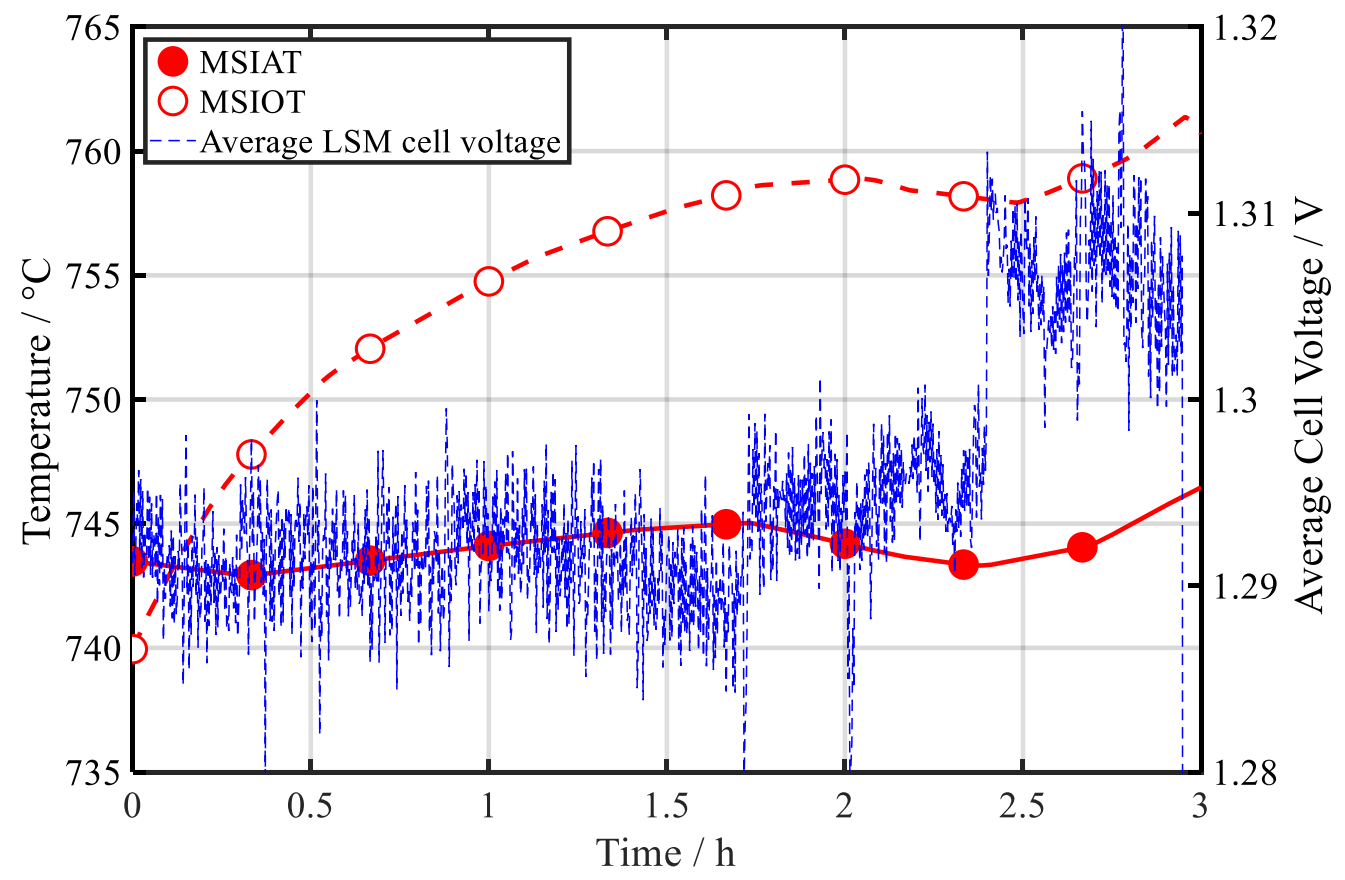

Figure 9: Air temperature profiles depending on operational voltage. MSI/OAT: mean stack inlet/outlet air temperature.

\subsection{Short Term Galvanostatic Operation}

Following the recording of the performance map, a durability step in galvanostatic operation was started. The chosen conditions were $22.2 \mathrm{~kg} \mathrm{~h}^{-1} \mathrm{H}_{2} \mathrm{O}$ and $51 \mathrm{NL} \mathrm{min}^{-1} \mathrm{H}_{2}$ (corresponding to $90 / 10$ vol. $\left.\% \mathrm{H}_{2} \mathrm{O} / \mathrm{H}_{2}\right)$, -192 A and 70\% SC. Results displayed in Figure 10 showed limited dispersion of outlet temperatures. The experiment was cut short after only $170 \mathrm{~h}$ due to the loss of one of the air preheaters. Unsurprisingly, given the short duration of the experiment, no significant evolutions of stack voltages were recorded. LSM operation in electrolysis mode over thousands of hours would next be required to further validate the stability of the LSM in operation and measure the degradation rate of its large stacks when operated in electrolysis mode. 

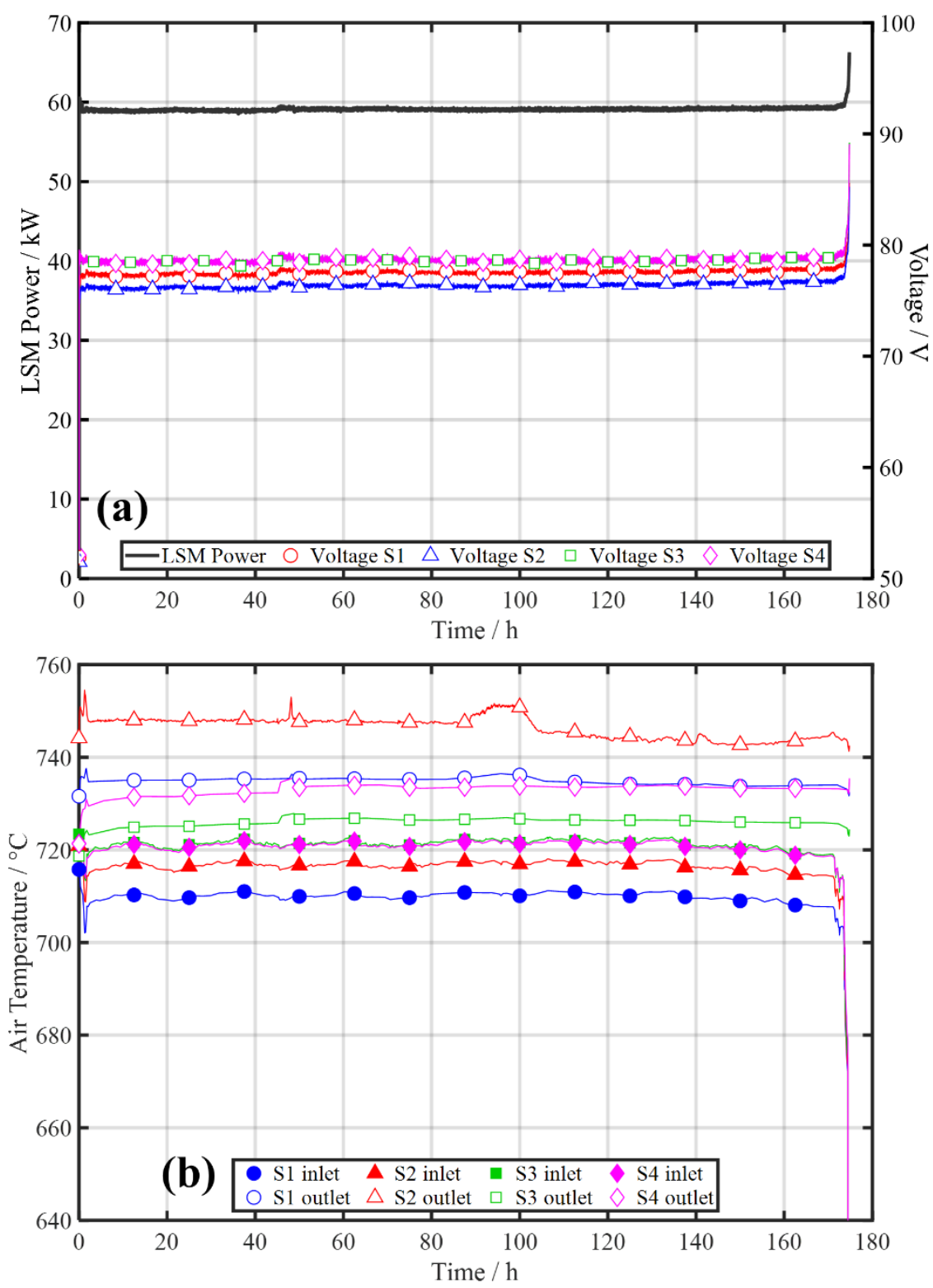

Figure 10: Time evolutions of (a) LSM power and stack voltages, (b) air temperatures and (c) fuel temperatures during short-term galvanostatic operation. Conditions were $22.2 \mathrm{~kg} \mathrm{~h}^{-1} \mathrm{H}_{2} \mathrm{O}, 51 \mathrm{NL} \mathrm{min}^{-1} \mathrm{H}_{2},-192 \mathrm{~A}, 70 \% \mathrm{SC}$. 


\section{Conclusions}

The present paper reports the test of SOLIDpower's Large Stack Module (LSM) in electrolysis mode on a test platform designed for high power reversible modules.

From a thermal perspective, the LSM showed excellent performances throughout the entire protocol. Losses in the range of $1 \mathrm{~kW}$ were recorded, corresponding to only a few percent of the module nominal power. In addition, results showed that while the heated-through-air LSM showed good thermal behavior during startups and shutdowns, a ramp rate of $0.5^{\circ} \mathrm{C} \mathrm{min}^{-1} \mathrm{might}$ require a steady state segment mid-way to allow homogenization of temperature gradients.

The stacks showed low performance dispersion and reacted well to fast power ramps, leading to a homogeneous power density throughout the module. This control strategy turned out to be well suited for electrolysis operation, avoiding endothermic operation and stabilizing to some extent the temperature fields. Extending the recording of a part-load polarization curve in SOFC- $\mathrm{H}_{2}$ mode to $90 \%$ fuel utilization at the module level highlighted excellent distribution of the fuel flowrate over the four stacks.

The main objectives of this work was to record a performance map, which yielded a production range of 39 to $52 \mathrm{~kg} \mathrm{day}^{-1} \mathrm{H}_{2}$ over 710 to $745^{\circ} \mathrm{C}$. At peak power, the DC power-to- $\mathrm{H}_{2}$ energy cost was $35.5 \mathrm{kWh}_{\mathrm{DC}} \mathrm{kgH}_{2}{ }^{-1}$. The near-isothermal current was shown to be mainly controlled by the stack temperature over the investigated range of steam flowrates. A short, $170 \mathrm{~h}$ steady state experiment was carried out, only interrupted due to component failure. No significant degradation was evidenced.

In the end, the modular design of the LSM seems well suited for system scale up, in particular in terms of ease of connection to centralized fuel and process air networks, paving the way to mutualization of auxiliaries and CAPEX reduction. 


\section{References}

[1] J. Laurencin and J. Mougin, Chp 6 - Hydrogen Production: By Electrolysis. John Wiley \& Sons, 2015.

[2] "The European Green Deal," European Commission, 2019.

[3] "Green Hydrogen for a European Green Deal A 2x40 GW Initiative," Hydrogen Europe, 2020.

[4] "A hydrogen strategy for a climate-neutral Europe," European Commission, 2020.

[5] "Strategic Research and Innovation Agenda," Hydrogen Europe, 2020.

[6] A. Brisse, M. Zeller, B. Ludwig, and J. Brabandt, "Solid Oxide Electrolyser System operational at the $\mathrm{H} 2$ refueling station of Karlsruhe," in 13th European SOFC \& SOE Forum, Lucerne, Switzerland, 2018, vol. A1101, pp. 5-15.

[7] "SALCOS project." [Online]. Available: https://salcos.salzgitter-ag.com/en/index.html.

[8] "Paving the way to green ammonia and low-carbon fertilizers," Fertilizers Europe, 2020.

[9] J. B. Hansen and P. V. Hendriksen, "The SOC4NH3 Project. Production and Use of Ammonia by Solid Oxide Cells," ECS Transactions, vol. 91, no. 1, pp. 2455-2465, Jul. 2019.

[10] O. Posdziech, K. Schwarze, and J. Brabandt, "Efficient hydrogen production for industry and electricity storage via high-temperature electrolysis," International Journal of Hydrogen Energy, vol. 44, no. 35, pp. 19089-19101, Jul. 2019.

[11] O. Posdziech, T. Geißler, K. Schwarze, and R. Blumentritt, "System Development and Demonstration of Large-Scale High-Temperature Electrolysis," ECS Transactions, vol. 91, no. 1, pp. 2537-2546, Jul. 2019.

[12] “GrInHy2.0 project website.” [Online]. Available: https://www.green-industrialhydrogen.com/.

[13] K. Schwarze, R. Blumentritt, T. Geißler, and H. Richter, "Demonstration of HighTemperature (Co-)Electrolysis Systems and their Evolution towards Multi-MW Scale," in 14th European SOFC \& SOE Forum 2020, Lucerne, Switzerland, 2020, p. 11.

[14] E. Lay-Grindler, J. Laurencin, G. Delette, J. Aicart, M. Petitjean, and L. Dessemond, "Micro modelling of solid oxide electrolysis cell: From performance to durability," International Journal of Hydrogen Energy, vol. 38, no. 17, pp. 6917-6929, juin 2013.

[15] E. Effori et al., "An Elementary Kinetic Model for the LSCF and LSCF-CGO Electrodes of Solid Oxide Cells: Impact of Operating Conditions and Degradation on the Electrode Response," Journal of The Electrochemical Society, vol. 168, no. 4, p. 044520, Apr. 2021.

[16] M. Hubert, J. Laurencin, P. Cloetens, B. Morel, D. Montinaro, and F. Lefebvre-Joud, "Impact of Nickel agglomeration on Solid Oxide Cell operated in fuel cell and electrolysis modes," Journal of Power Sources, vol. 397, pp. 240-251, Sep. 2018.

[17] A. Hauch, A. Ploner, S. Pylypko, G. Cubizolles, and J. Mougin, "Test and characterization of reversible solid oxide cells and stacks for innovative renewable energy storage," Fuel Cells, Oct. 2021.

[18] Q. Fang, C. E. Frey, N. H. Menzler, and L. Blum, "Electrochemical Performance and Preliminary Post-Mortem Analysis of a Solid Oxide Cell Stack with 20,000 h of Operation," Journal of The Electrochemical Society, vol. 165, no. 2, pp. F38-F45, 2018.

[19] M. Frank, R. Deja, R. Peters, L. Blum, and D. Stolten, "Bypassing renewable variability with a reversible solid oxide cell plant," Applied Energy, vol. 217, pp. 101-112, May 2018.

[20] J. Aicart, S. Di Iorio, M. Petitjean, P. Giroud, G. Palcoux, and J. Mougin, “Transition Cycles during Operation of a Reversible Solid Oxide Electrolyzer/Fuel Cell (rSOC) System," Fuel Cells, May 2019. 
[21] A. Nechache and S. Hody, "Test and Evaluation of an Hybrid Storage Solution for Buildings, Based on a Reversible High-Temperature Electrolyzer," ECS Transactions, vol. 91, no. 1, pp. 2485-2494, Jul. 2019.

[22] M. Lamagna, B. Nastasi, D. Groppi, C. Rozain, M. Manfren, and D. Astiaso Garcia, "Techno-economic assessment of reversible Solid Oxide Cell integration to renewable energy systems at building and district scale," Energy Conversion and Management, vol. 235, p. 113993, May 2021.

[23] V. Saarinen et al., "Design, manufacturing, and operation of movable $2 \times 10 \mathrm{~kW}$ size rSOC system," Fuel Cells, p. 11, 2021.

[24] Ro. Peters et al., "Long-Term Experience with a 5/15kW-Class Reversible Solid Oxide Cell System," Journal of the Electrochemical Society, vol. 168, no. 1, p. 014508, Jan. 2021.

[25] A. Arsalis, "A comprehensive review of fuel cell-based micro-combined-heat-and-power systems," Renewable and Sustainable Energy Reviews, vol. 105, pp. 391-414, May 2019.

[26] T. de A. Ferreira, Z. Wuillemin, A. G. Marchetti, and D. Bonvin, "Fast RTO Applied to a Commercial SOFC System," IFAC-PapersOnLine, vol. 52, no. 1, pp. 40-45, 2019.

[27] S. Santhanam et al., "Experimental Analysis of a $25 \mathrm{kWe}$ Solid Oxide Fuel Cell Module for Co-Generation of Hydrogen and Power," ECS Transactions, vol. 91, no. 1, pp. 159166, Jul. 2019.

[28] H. Moussaoui et al., "Stochastic geometrical modeling of solid oxide cells electrodes validated on 3D reconstructions," Computational Materials Science, vol. 143, pp. 262 276, Feb. 2018.

[29] J. Laurencin, D. Kane, G. Delette, J. Deseure, and F. Lefebvre-Joud, "Modelling of solid oxide steam electrolyser: Impact of the operating conditions on hydrogen production," Journal of Power Sources, vol. 196, no. 4, pp. 2080-2093, février 2011.

[30] J. Aicart, M. Petitjean, J. Laurencin, L. Tallobre, and L. Dessemond, “Accurate predictions of $\mathrm{H} 2 \mathrm{O}$ and $\mathrm{CO} 2$ co-electrolysis outlet compositions in operation," International Journal of Hydrogen Energy, vol. 40, pp. 3134-3148, 2015.

[31] S. Di Iorio et al., "SOE stack activities at CEA," in 11th European SOFC \& SOE Forum, Lucerne, Switzerland, 2014, vol. B1307, pp. 1-8.

[32] A. Chatroux et al., "A Packaged and Efficient SOEC System Demonstrator," ECS Transactions, vol. 68, no. 1, pp. 3519-3526, Jul. 2015.

[33] A. Chatroux et al., "Power to Power efficiencies based on a SOFC/SOEC reversible system," in 12th European SOFC \& SOE Forum, Lucerne, Switzerland, 2016, vol. B1104, pp. 222-230.

[34] "An experimental platform to test rSOC modules up to 120kWDC set up at CEA," LITEN CEA. [Online]. Available: https://liten.cea.fr/ceatech/liten/english/Pages/Medias/News/Hydrogen-Vector/An-experimental-platform-totest-rSOC-modules.aspx.

[35] M. Reytier et al., "Stack performances in high temperature steam electrolysis and coelectrolysis," International Journal of Hydrogen Energy, vol. 40, no. 35, pp. 1137011377, Sep. 2015.

[36] B. Todd and J. B. Young, "Thermodynamic and transport properties of gases for use in solid oxide fuel cell modelling," Journal of Power Sources, vol. 110, no. 1, pp. 186-200, juillet 2002.

[37] Bruce E. Poling, John M. Prausnitz, and John P. O'Connell, Properties of Gases and Liquids, Fifth Edition. New York: McGraw-Hill Education, 2001. 